\title{
INOVASI PEMBELAJARAN PENULISAN NASKAH DRAMA ANAK DENGAN MENGGUNAKAN STRATEGI IDCD (IDENTIFICATION, DESIGN, CHANGE, AND DEVELOPMENT)
}

\author{
Fiyan IIman Faqih \\ Universitas Trunojoyo Madura \\ Email: fiyan.faqih@trunojoyo.ac.id
}

\begin{abstract}
Abstrak
Penulisan naskah drama anak merupakan keterampilan yang masih kurang berkembang. Hal itu terjadi karena mahasiswa tidak paham tentang siapa anak-anak dan bagaimana karkakteristik anakanak. Salah satu cara penyelesaian masalah tersebut ialah mengadakan inovasi strategi pembelajaran. Inovasi strategi tersebut ialah IDCD (identification, design, change, dan development). Strategi ini diciptakan untuk kebutuhan keterampilan menulis, khususnya menulis naskah drama anak bagi mahasiswa. Strategi diciptakan untuk menciptakan pembelajaran penulisan naskah drama anak yang lebih kreatif, inovatif, dan naskah drama anak yang diciptakan sesuai dengan tingkat perkembangan anak.
\end{abstract}

Kata kunci: inovasi pembelajaran, penulisan naskah drama anak, strategi IDCD.

\section{Abstract}

The writing children's drama scripts is an underdeveloped skill. This happens because students not understand who children and how characteristic children. One way to solve this problem is to innovate learning strategies. The strategic innovation is IDCD (identification, design, change, and development). This strategy was created for the needs of writing skills, especially writing children's drama scripts for students. Strategies were created to create learning more creative, innovative children's drama script writing, and children's drama scripts that are created according to the child's level of development.

Keywords: learning innovation, children's drama script writing, IDCD strategy.

\section{PENDAHULUAN}

Menulis merupakan salah satu keterampilan berbahasa yang sangat penting untuk dikuasai. Tarigan (2008:3) menjelaskan bahwa menulis ialah komunikasi tidak langsung. Menulis juga mengandung lima aspek komunikasi, yaitu (1) penyampai pesan, (2) pesan yang disampaikan, (3) media, (4) penerima pesan, dan (5) efek. Oleh karena itu, Suyono dan Muslich (2010:52) menjelaskan bahwa ada tiga hal yang harus dikuasi, yaitu (1) penguasaan bahasa tulis, (2) pengusaan isi, dan (3) pengusaan tentang jenis tulisan. Ketiga hal tersebut juga berlaku pada penulisan naskah drama anak. Kegiatan penulisan naskah drama anak merupakan kegiatan menyampaikan gagasan dalam bentuk naskah drama yang sesuai dengan tingkat perkembangan fisik, kognitif, dan sosioemosi anak-anak. Kegiatan tersebut tidak hanya penting dilakukan oleh anak-anak, tetapi kegiatan tersebut juga penting dilakukan oleh mahasiswa. Kegiatan itu penting dilakukan oleh mahasiswa karena mempunyai tiga manfaat.
Pertama, memperkaya ragam penulisan naskah drama. Kedua, sarana untuk memperlajari kehidupan anak-anak. Kurniawan (2009:22) menjelaskan bahwa drama anak juga harus ditulis dan dibaca oleh orang dewasa agar orang dewasa agar semakin tahu dan memahami dunia anakanak. Ketiga, sarana untuk menanamkan nilainilai pendidikan. Sebagaimana yang dijelaskan oleh Winarni (2014:1) bahwa naskah drama anak dapat digunakan sebagai sarana untuk menanam, memupuk, mengembangkan, dan melestarikan nilai-nilai pendidikan.

Besarnya manfaat penulisan naskah drama anak tidak sebesar praktiknya. Sedikitnya mahasiswa yang pernah menulis naskah drama anak bukan karena mereka tidak suka dengan naskah drama anak. Akan tetapi, karena mereka belum mengerti siapa dan bagaimana anak-anak. Walaupun secara tingkat perkembangan, mereka mengalami tahap anak-anak, bukan berarti mereka paham seutuhnya siapa dan bagaimana anak-anak. Pada saat mereka tidak paham tentang siapa dan bagaimana anak-anak, mereka 
cenderung akan menulis naskah drama anak yang berasal dari sudut pandang orang dewasa. Hal itu sebenarnya lumrah karena untuk menciptakan pemikiran anak-anak pada tahap perkembangan orang dewasa itu sangat sulit. Salah satu cara penyelesaian masalah tersebut ialah mengadakan inovasi strategi pembelajaran. Inovasi strategi tersebut ialah IDD (identification, design, change, dan development). Strategi diciptakan untuk menciptakan pembelajaran penulisan naskah drama anak yang lebih kreatif dan inovatif.

\section{STRATEGI IDCD}

Strategi IDCD adalah strategi yang terdiri atas empat tahap. Pertama, tahap identifikasi ialah tahap untuk mengindetifikasi kasi sebuah objek yang ada menjadi dasar dalam penulisan naskah drama anak. Ada sebuah objek yang harus diidentifikasi, yaitu anak-anak. Kegiatan itu perlu dilakukan agar penulis paham siapa dan bagaimana anak-anak tersebut. Jika penulis paham tentang anak-anak, maka naskah drama anak yang ditulis akan sesuai dengan tingkat perkembangan anak-anak. Sebagaimana yang dijelaskan oleh Kurniawan (2009:5) menjelaskan bahwa pada aspek internal sastra anak-anak (naskah drama anak-anak) bersifat tertutup, yakni isi harus disesuaikan dengan perkembangan intelektual dan emosional anak-anak.

Kedua, tahap desain merupakan tahap merancang unsur naskah dalam naskah drama anak. Tahap ini harus berdasarkan pada hasil identifikasi anak-anak. Secara umum, tahap ini diadaptasi dari lima langkah menulis naskah drama dengan memperhatikan kaidah penulisan naskah yang dikembangkan oleh Pratiwi dan Siswiyanti. Pratiwi dan Siswiyanti (2014:181) menyebutkan langkah-langkah menulis naskah drama, yaitu (1) memilih objek/menentukan sumber ide penulisan, (2) penentuan tema cerita, (3) pemilihan tokoh dalam cerita, (4) pemilihan latar cerita, dan (5) merancang kerangka alur. Dari kelima langkah tersebut diadaptasi menjadi tujuh langkah, yaitu (1) menetukan ide, (2) menentukan tema, (3) menetukan amanat, (4) menentukan tokoh, (5) menentukan perwatakan, (6) menentukan latar, dan (7) menentukan alur. Pada setiap langkah tersebut mengadaptasi metode Enam Topi Berpikir (The Six Thinking Hats) yang dikembangkan oleh Bono. Metode Enam Topi Berpikir adalah metode pembelajaran untuk mengerjakan satu jenis kegiatan berpikir pada satu keadaan (Bono, 2007:95). Metode enam topi berpikir memungkinkan kita untuk mengatur pikiran kita, seperti halnya seorang pemimpin yang mengatur orkestra.

Ketiga, tahap perubahan merupakan tahap merubah tokoh menjadi tokoh dan latar yang menjadi latar yang lebih sesuai dengan tokoh tersebut. Tokoh-tokoh yang muncul dalam naskah drama anak-anak tidak harus anak-anak, bisa tokoh yang berupa orang dewasa, boneka, binatang, tumbuhan, bahkan benda. Hal itu dilakukan agar naskah drama anak yang ditulis lebih menarik perhatian anak-anak. Akan tetapi, sikap dan tingkah laku tokoh boneka, binatang, tumbuhan, dan benda tersebut harus tetap menyerupai manusia. Sebagaimana penjelasan Nurgiyantoro (2013:9) bahwa karakter tokoh dalam sastra anak-anak, khususnya naskah drama anak-anak lebih merujuk pada karakter yang sederhana dan familiar sehingga anak-anak merasa dekat dan sudah mengenali. Contohnya, tokoh binatang yang dapat berbicara, berperilaku, berpikir, dan berperasaan layaknya manusia. Selain itu, tokoh-tokoh yang dimunculkan dalam naskah drama anak-anak tersebut harus tokohtokoh yang dekat dengan kehidupan anak-anak, misalnya teman sejawat, guru, ibu, ayah, adik, kambing, kucing, pohon, dan lain-lain sebagainya.

Keempat, tahap mengembangkan merupakan tahap penulisan naskah drama anak. Penulisan naskah drama anak harus berdasarkan hasil rancangan yang telah dibuat. Tahap ini juga didaptasi dari metode Enam Topi Berpikir yang dikembangkan oleh Bono.

\section{TARGET STRATEGI IDCD}

Penerapan strategi IDCD dalam pembelajaran penulisan naskah drama anak bukan dilakukan oleh anak-anak, tetapi dilakukan oleh mahasiswa. Oleh karena itu, secara umum target penggunaan strategi IDCD ini agar mahasiswa dapat menulis naskah drama anak yang menarik dan sesuai dengan tingkat perkembangan anak-anak. Sementara itu, lebih khusus target penggunaan strategi IDCD dalam pembelajaran penulisan naskah drama anak, yaitu:

1. Mahasiswa dapat mengidentifikasi anak-anak, baik fisik, kognitif, dan sosioemosi.

2. Mahasiswa dapat menentukan, ide, tema, amanat, tokoh dan penokohan, latar, dan alur yang sesuai dengan tingkat perkembangan anak-anak. 
3. Mahasiwa dapat mengubah rancangan menjadi rancangan baru yang lebih menarik dan sesuai dengan tingkat perkembangan anak-anak.

4. Mahasiswa dapat mengembangkan rancangan naskah drama anak menjadi naskah drama anak yang utuh dan sesuai dengan tingkat perkembangan anak-anak

\section{LANDASAN STRATEGI IDCD}

Ada empat landasan penciptaan strategi IDCD, yaitu (1) projek based learning, (2) cooperatif learning, (3) brainstorming, dan (4) enam topi berpikir.

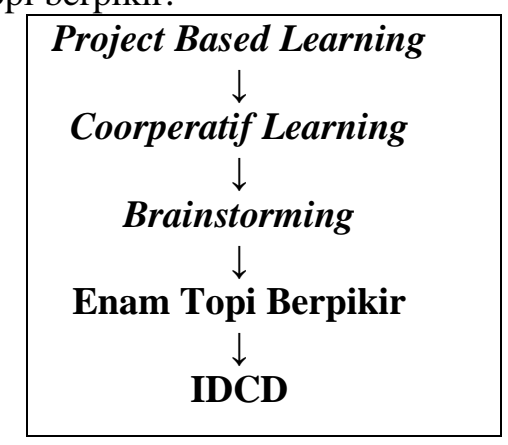

\section{1) Project Based Learning}

Model pembelajaran project based learning atau biasa kita kenal dengan sebuatan pembelajaran berbasis proyek merupakan model pembelajaran yang menekankan mahasiswa untuk bekerja secara mandiri. Sebagaimana yang dijelaskan oleh Buck Institute for Education (dalam Nurhadi dan Senduk, 2009:89) bahwa model ini memperkenankan peserta didik untuk bekerja secara mandiri dalam mengonstruk (membentuk) pembelajarannya dan mengkulminasikannya dalam produk nyata. Selain itu, pembelejaran ini merupakan model pembelajaran yang membuat mahasiswa lebih kreatif dan inovatif. Sebagaimana yang dijelaskan oleh Wena (2010:145) bahwa mode belajar project based learning adalah model pembelajaran yang inovatif dalam mengajarkan mengenai konsep-konsep dalam materi ajar. Hal itu terjadi karena model ini memberikan kebebasan berpikir dan berkreasi kepada mahasiswa. Daryanto (2009:407) menjelaskan bahwa project based learning merupakan cara belajar yang memberikan kebebasan berpikir pada peserta didik yang berkaitan dengan isi atau bahan pengajaran dan tujuan yang direncanakan. Fokus model pembelajaran ini terletak pada kegiatan identifikasi dan menghasilkan sebuah produk yang berdasarkan hasil identifikasi tersebut. Gora dan Sunarto (2010:119) menjelaskan bahwa ada empat karakteristik pada model pembelajaran project based learning. Pertama, mengembangkan pertanyaan atau masalah, yang berarti pembelajaran harus mengembangkan pengetahuan yang dimiliki oleh siswa. Kedua, memiliki hubungan dengan dunia nyata, berarti bahwa pembelajaran yang outentik dan siswa dihadapkan dengan masalah yang ada pada dunia nyata. Ketiga, menekankan pada tanggung jawab siswa, merupakan proses siswa untuk mengakses informasi untuk menemukan solusi yang sedang dihadapi. Keempat, penilaian dilakukan selama proses pembelajaran berlangsung dan hasil proyek yang dikerjakan siswa.

Rais (2010:8-9) menjelaskan ada enam langkah dalam model pembelajaran project based learning, yaitu:

(1) Start with essential question: pembelajaran dimulai dengan pertanyaan esesnsial, yaitu pertanyaan yang dapat memberi penugasan siswa dalam melakukan suatu aktivitas.

(2) Design a plan for the project: perencanaan berisi tentang aturan main dan waktu yang diperlukan setiap masing-masing kelompok untuk menyelesaikan proyek.

(3) Create a schedule: aktivitas pembuatan jadwal mengerjakan proyek dan membuat deadline penyelesaian proyek.

(4) Monitoring the student and the of the project: guru melakukan bantuan-bantuan kecil selama proses pengerjaan proyek, dengan menayakan sampai mana, bagaimana yang belum terselesaikan dan ada kesulitan atau tidak.

(5) Assess the outcome: penilaian dilakukan untuk membantu pengajar dalam mengukur ketercapaian hasil standar.

(6) Evaluate the experience: pada akhir proses pembelajaran, pengajar dan siswa melakukan refleksi terhadap aktivitas dan hasil proyek yang sudah dijalankan.

Model ini terlihat dalam kegiatan mengdientifikasi anak-anak hingga menciptakan sbeuah produk, yakni sebuah naskah drama anakanak. Pemilihan model project based learning untuk menjadi landasaan penciptaan strategi IDCD itu karena banyak memiliki keuntungan. Daryanto (2009:408-409) menjelaskan bahwa keuntungan menggunakan metode pembelajaran berbasis proyek, yaitu (1) meningkatkan motivasi belajar siswa, (2) meningkatkan kemampuan dan kreativitas siswa untuk membuat proyek, (3) 
meningkatkan kolaboratif atau peran kerjasama kelompok disetiap siswa, (4) mengembangkan kemampuan merencanakan, dan (5) mengembangkan sikap gotong royong, hidup demokrasi serta rasa tanggungjawab tinggi. Selain itu, yang paling penting ialah mahasiswa dapat memahami siapa dan bagaimana anak-anak yang mereka identifikasi.

\section{2) Cooperative Learning}

Cooperative ialah mengerjakan sesuatu secara bekerjasama sebagai satu kelompok. Solihatin dan Raharjo (2007:4-5) menjelaskan bahwa model pembelajaran cooperative learning berangkat dari asumsi mendasar dalam kehidupan masyarakat, yakni getting better together. Maka dair itu, cooperative learning adalah sistem pembelajaran yang terdapat kegiatan kerjasama antar mahasiswa yang dilakukan dalam kelompok-kelompok kecil yang berjumlah 4-6 orang secara kolaboratif. Stahl (dalam Solihatin dan Raharjo, 2007:6-9) menyebutkan prinsipprinsip dasar dalam cooperative learning, yaitu (1) perumusan tujuan belajar peserta didik harus jelas, (2) penerimaan menyeluruh oleh peserta didik tentang tujuan belajar, (3) ketergantungan yang sangat positif, (4) interaksi yang bersifat terbuka, 5) tanggung jawab individu, (6) kelompok bersifat heterogen, (7) interaksi sikap dan perilaku sosial yang positif, (8) tindak lanjut (follow up), dan (9) kepuasan dalam belajar. Pembelajaran cooperative learning berbeda dengan kegiatan kerja kelompok lainnya. Isjoni (2011:41) menejelaskan bahwa ada lima hal yang membedakan cooperative learning dengan kerja kelompok lainnya, yaitu (1) positive independence, (2) interaction face to face, (3) adanya tanggung jawab pribadi mengenai materi pelajaran dalam anggota kelompok, (4) membutuhkan keluwesan, dan (5) meningkatkan keterampilan bekerja sama dalam memecahkan masalah.

Model ini terlihat dalam kegiatan mengidentifikasi anak-anak. Pemilihan model cooperative learning untuk menjadi landasan inovasi pembelajaran penulisan naskah drama anak dengan menggunakan strategi IDCD karena memiliki banyak keuntungan. Pertama, interakasi antar mahasiswa semakin meningkat. Kedua, meningkatkan memiliki tanggung jawab kelompok dan individual. Ketiga, memiliki pemahaman tentang anak-anak yang lebih komperehensif.

\section{3) Brainstorming}

Brainstorming (curah pendapat) adalah praktik teknik konferensi sebuah kelompok yang berupaya mencari solusi atas masalah tententu dengan menhimpun semua ide yang disampaikan oleh para anggotanya. Osborn (dalam Gie, 1995) menjelaskan bahwa ada empat ketentuan dalam pelaksanakan brainstorming yaitu (a) kritik tidak diperkenankan, (b) penggalian ide secara bebas dianjurkan, (c) kualitas lebih diharapkan, dan (d) penggabungan dan penyampuran dicari. Ada beberapa manfaat yang diperoleh dalam melakukan teknik brainstorming. Adapun manfaat tersebut, yaitu pertama, mengidentifikasi masalah: teknik brainstorming cukup efektif untuk menyelidiki sebab akibat terjadinya masalah karena masing-masing peserta diskusi akan mengeksplorasi faktor-faktor pemicu masalah. Kedua, menganalisis situasi: peserta diskusi akan menganalisis permasalahan dan situasi yang dihadapi oleh tim kerja tersebut saat ini. Ketiga, mengalirkan ide-ide baru: manfaat utama dari teknik brainstorming adalah mendapatkan ide sebanyak mungkin dari para anggota. Keempat, menganalisis ide-ide: aliran ide-ide segar dan inovatif dari peserta diskusi akan dianalisis dalam sebuah diskusi lanjutan. Kelima, menentukan alternatif pemecahan masalah: diskusi menentukan alternatif pemecahan masalah berdasarkan ide-ide yang telah disepakati bersama. Keenam, merencanakan langkah-langkah dan kegiatan yang akan dilakukan untuk memperbaiki masalah: salah satu manfaat dari teknik ini adalah untuk menyusun langkah-langkah berikutnya sebagai upaya perbaikan masalah. Berdasarkan manfaatmanfaat tersebut, maka teknik brainstorming menjadi landasan dalam penciptaan strategi IDCD. Brainstorming dalam strategi IDCD tercemin dalam kegiatan mengkomparasikan semua hasil identifikasi tentang anak-anak menjadi semua pemahaman tentang anak-anak yang utuh.

\section{4) Enam Topi Berpikir}

Enam topi berpikir adalah metode pembelajaran untuk mengerjakan satu jenis kegiatan berpikir yang dikembangkan oleh Edward De Bono. Bono (1990:35) membagi keenam topi tersebut menjadi warna yang berbeda-beda, yaitu topi warna putih, merah, hitam, kuning, hijau, dan biru. Pertama, topi putih merupakan kegiatan berpikir berdasarkan fakta. Pemikir berusaha lebih netral dan lebih 
objektif terhadap informasi. Kedua, topi merah merupakan kegiatan berpikir berdasarkan emosi. Topi merah membuat perasaan terlihat sehingga perasaan tersebut dapat menjadi bagian dari peta berpikir. Topi merah meliputi dua jenis perasaan, yaitu rasa yang pertama meliputi ketakutan, kecurigaan, ketidaksenangan, cinta, senang, dan lain-lain, dan yang kedua terkait dengan firasat, intuisi, indera, dan lain-lain. Ketiga, topi hitam merupakan kegiatan berpikir yang secara khusus menyangkut penilaian negatif. Pemikir topi hitam menunjukkan bagaimana suatu hal tidak sesuai dengan pengalaman dan pengetahuan pemikir. Pemikir topi hitam menunjukkan berbagai resiko dan bahaya yang mungkin terjadi. Keempat, topi kuning merupakan kegiatan berpikir dari segi positif dan konstruktif. Berpikir topi kuning meliputi hal-hal positif dan memperoleh keuntungan. Kelima, topi hijau merupakan kegiatan berpikir kreatif. Aspek fundamental dari berpikir topi hijau ialah pencarian berbagai alternatif. Keenam, topi biru merupakan pengatur kegiatan berpikir. Berpikir topi biru bertugas untuk membuat ikhtisar, tinjauan luas, dan kesimpulan. Bono (2007:121) berpendapat pada dasarnya penggunaan metode Enam Topi Berpikir itu sangat bervariasi sesuai dengan kebutuhan yang kita inginkan. Akan tetapi, terdapat tiga aturan atau panduan yang bisa diterapkan dalam pemakaiannya, yaitu (1) setiap topi dapat digunakan lebih dari satu kali, (2) sebaiknya mendahulukan menggunakan topi kuning sebelum menggunakan topi hitam karena sulit bersikap positif setelah bersikap penuh kritik, dan (3) topi hitam digunakan dengan dua cara, yakni untuk menunjukkan kelemahan suatu ide dan untuk melakukan penilaian. Dalam strategi IDCD metode enam topi berpikir digunakan dalam kegiatan desain dan pengembangan naskah drama anak.

\section{KARAKATERISTIK STRATEGI IDCD}

Ada beberapa karakteristik yang terkandung dalam strategi IDCD, yaitu:

(1) Terdapat kegiatan berkelompok

(2) Terdapat tugas individu dalam kelompok

(3) Terdapat kegiatan mengidentifikasi anakanak

(4) Terdapat kegiatan mengkomprasikan temuan dari hasil identifikasi anak-anak

(5) Mendapatkan pemahaman yang utuh tentang anak-anak

(6) Terdapat kegiatan merancang naskah drama anak
(7) Terdapat kegiatan mengubah tokoh menjadi tokoh hewan

(8) Terdapat kegiatan meneliti ulang rancangan

(9) Terdapat kegiatan mengembangkan rancangan menjadi naskah drama anak yang utuh

(10) Terdapat kegiatan merevisi naskah drama anak-anak

\section{LANGKAH-LANGKAH PELAKSANAAN STARTEGI IDCD}

Adapun langkah-langkah pelaksanaan strategi IDCD, yaitu:

(1) Dosen menjelaskan tujuan pembelajaran yang akan dilaksanakan oleh mahasiswa

(2) Dosen membagi kelas menjadi empat kelompok yang terdiri atas 4-6 mahasiswa.

(3) Dosen membagikan satu lembar kerja kepada setiap anggota kelompok. Lembar kerja tersebut berisi empat kolom. Kolom pertama berisi tentang nama anak. Kolom kedua berisi kolom umur. Kelom ketiga jenis kelamin. Kolom keempat berisi aspek identifikasi yang terdiri atas tiga aspek, yaitu fisik, kognitif, dan sosioemosi.

(4) Dosen juga memberikan satu lembar kerja kepada masing-masing kelompok. Lembar kerja tersebut berisi tiga kolom. Kolom pertama berisi jenis kelamin. Kolom kedua berisi umur. Kolom ketiga berisi aspek yang terdiri tiga aspek, yaitu fisik, kognitif, dan sosioemosi.

(5) Dosen menjelaskan bahwa setiap anggota kelompok mempunyai tugas individu, yakni mengidentifikasi seorang anak yang sesuai dengan lembar kerja dan kriteria yang telah ditentukan. Kelompok pertama mengidentifikasi anak laki-laki kelas rendah SD (kelas 1, 2, dan 3). Kelompok kedua mengidentifikasi anak perempuan kelas rendah SD (kelas 1, 2, da 3). Kelompok ketiga mengidentifikasi anak laki-laki kelas tinggi SD (kelas 4, 5, dan 6). Kelompok keempat mengidentifikasi anak perempuan kelas tinggi SD (kelas 4, 5, dan 6).

(6) Setelah itu, kelompok berkejasama untuk mengkomparasikan hasil identifikasi menjadi sebuah hasil identifikasi yang lebih komperehensif.

(7) Jika hasil identifikasi yang lebih komperehensi sudah diketahui, maka setiap anggota harus membuat rancangan naskah drama anak berdasarkan hasil identifikasi tersebut. Mulai dari ide, tema, amanat, 
tokoh, perwatakan, latar, dan alur. Langkahlangkah membuat rancangan tersebut mengadabtasi metode enam topi berpikir. Oleh karena itu, setiap aspek terdiri atas tiga kegiatan, yaitu mencari (berpikir berdasarkan fakta), memeriksa (berpikir positif dan negatif), dan merumuskan (berpikir kreatif).

(8) Setelah rancangan itu selesai, barulah tokoh diubah menjadi tokoh hewan. Hal itu dilakukan agar naskah drama yang dibuat lebih menarik.

(9) Kegiatan terakhir ialah mengembangkan rancangan tersebut menjadi naskah drama anak-anak yang utuh. Setelah utuh, barulah naskah drama anak tersebut direvisi kembali hingga menjadi naskah drama anak yang lebih menarik dan sesuai dengan tingkat perkembangan anak-anak.

\section{KELEBIHAN DAN KEKURANGAN STARTEGI IDCD}

Inovasi pembelajaran menulis naskah drama anak dengan menggunakan strategi IDCD memiliki kelebihan. Akan tetapi, juga tidak lepas dari kekurangan. Adapun kelebihan dan kekurangan strategi IDCD, yaitu:

(1) Kelebihan

(a) Mendorong mahasiswa untuk berpikir kritis tentang anak-anak

(b) Mendorong mahasiswa untuk berpikir sistematis dalam merancang naskah drama anak

(c) Mendorong mahasiswa untuk berpikir kreatif dalam merancang dan menulis naskah drama anak

(d) Mahasiswa akan memiliki pemahaman yang utuh tentang karakteristik anakanak

(e) Naskah drama anak yang dirancang dan ditulis oleh mahasiswa akan sesuai dengan tingkat perkembangan anakanak

(2) Kekurangan

(a) Membuat proses penulisan naskah drama anak lebih lama

(b) Jika mahasiswa kurang aktif, mahasiswa tidak akan mendapatkan dapat tentang anak-anak.

\section{SIMPULAN}

Letak kesulitan menulis naskah drama anak bukan pada membuat naskah dramanya, tetapi terletak pada kesesuaian isi naskah drama anak dengan tingkat perkembangan anak-anak. Maka dari itu, untuk mengatasi kesulitan tersebut perlu diadakan inovasi pembelajaran. Salah satu inovasi tersebut ialah inovasi strategi pembelajaran. Inovasi tersebut ialah strategi IDCD. Strategi ini mempunyai empat landasan, yaitu project based learning, cooperative learning, dan brainstorming. Strategi ini mempunyai empat kegiatan inti, yaitu identifikasi, desain, pengubahan, dan pengembangan. Strategi ini membuat naskah drama anak yang ditulis oleh mahasiswa sesuai dengan tingkat perkembangan anak. Akan tetapi, proses penulisan naskah drama anak menjadi lebih lama.

\section{DAFTAR RUJUKAN}

Bono, D. E. 1990. Enam Topi Berpikir. Terjemahan Ridwan Max Sijabat. Jakarta: Erlangga.

Bono, D. E. 2007. Revolusi Berpikir. Terjemahan Ida Sitompul dan Fahmi Yamani. Bandung: Mizan.

Daryanto. 2009. Panduan Proses Pembelajaran Kreatif dan Inovatif (Teori dan Praktik dalam Pengembangan Profesionalisme bagi Guru). Jakarta: Publisher.

Gie, L. 1995. Cara Belajar yang Efisien, Jilid 2. Yogyakarta: Library.

Isjoni. 2011. Cooperative Learning Efektifitas Pembelajaran Kelompok. Bandung: Alfabeta.

Kurniawan, H. 2009. Sastra Anak dalam Kajian Strukturalisme, Sosiologi, Semiotika, hingga Penulisan Kreatif. Yogyakarta: Graha Ilmu.

Nurgiyantoro, B. 2013. Sastra Anak Pengantar Pemahaman Dunia Anak. Yogyakarta: Gadjah Mada University.

Nurhadi \& Senduk, A. D. 2009. Pembelajaran Konstektual (Contextual Teaching and Learning/CTL). Malang:

Rais, M. 2010. Project Based Learning: Inovasi Pembelajaran Yang Berorientasi Soft Skills. Makalan disajikan sebagai Makalah Pendamping dalam Seminar Nasional Pendidikan Teknologi dan Kejuruan Fakultas Teknik Universitas Negeri Surabaya tahun 2010. Surabaya: Unesa. Etin Solihatin dan Raharjo. 
(2007). Cooperative Learning. Jakarta: Bumi Aksara.

Suyono, \& Muslich, M. 2010. Aneka Model Pembelajaran Membaca dan Menulis. Malang: A3.

Wena, M. 2009. Strategi Pembelajaran Inovatif Kontemporer: Suatu Tinjauan Konseptual Operasional. Jakarta: Bumi Aksara.

Winarni, R. 2014. Kajian Sastra Anak. Yogyakarta: Graha Ilmu. 
Volume 5 No. 2 METALINGUA

Oktober 2020 Jurnal Pendidikan Bahasa dan Sastra Indonesia 